\title{
Modelling Tourism and Economic Growth Nexus in Africa: A Symmetric Panel ARDL Approach
}

\author{
Yunana Ishemu Zumba \\ Department of Economics \\ University of Jos \\ zumba348@gmail.com \\ Jos, Nigeria \\ Funmilayo Gift Adeshola \\ Department of Economics \\ University of Jos \\ funmilight92@gmail.com \\ Jos, Nigeria
}

\section{Oguama Sarah Chiagoziem \\ First Bank of Nigeria Limited sarahuguama@gmail.com \\ Lagos, Nigeria}

\section{Magai Abe}

Department of Economics

Federal University, Wukari

magaiabe22@gmail.com

Wukari, Nigeria

DOI: $10.31364 / \mathrm{SCIRJ} / \mathrm{v} 7.14 .2019 . P 0419643$

http://dx.doi.org/10.31364/SCIRJ/v7.i4.2019.P0419643

\begin{abstract}
We model the nexus between tourism and economic growth in Africa using annual data that runs from 1995-2016 for 48 African countries. We approach the study in two ways - all the selected African countries and each of the five regions of the continent distinctly. Symmetric panel Autoregressive Distributed Lag (ARDL) and Granger non-causality test were utilized for the study. Our empirical evidence affirms that tourism is indispensable for growth in Africa, Eastern, Northern, Southern and Western Africa in the long run. In the short run, tourism contributes insignificantly to growth in Central, Northern, Southern and Western Africa but insignificantly reduces growth in Africa and Eastern Africa. We observe an evidence of bidirectional causality between tourism and economic growth in Africa, Central, Eastern and Northern Africa, a unidirectional causality from growth to tourism in West Africa and from tourism to growth in Northern Africa. We therefore conclude that tourism drives economic growth in Africa.
\end{abstract}

Index Terms- Africa, Economic Growth, Granger Non-Causality, Symmetric Panel ARDL, Tourism. 


\section{INTRODUCTION}

One of the principal objectives of macroeconomic analysis, and by extension the goal of every economy is to attain a higher and sustainable level of economic growth and development. A country's ability to achieve this enviable goal depends on among other things, its capacity to generate enormous revenue (Zumba \& Adeshola, 2018). Hypothetically, tourism is essential in enhancing economic growth and development as it increases the revenue generation capacity of a country (be it a developing or developed) both directly and indirectly. However, not until the twenty first century, the role of tourism in economic growth has often been restrained and seen as a non-growth-oriented sector, hence attracting little attention of both economists and policymakers (Papatheodorou, 1999). Today, tourism has contributed immensely to the growth of global economy and has proven to be not only one of the fastgrowing service sectors, but also an indispensable factor in stimulating economic growth. Thus, tourism sector has attracted the attention of many researchers and policy makers globally in recent time.

It has been empirically verified that there exists a relationship between tourism and economic growth (Pablo-Romero \& Molina, 2013) and this relationship has been established to be positive and significant (Ohlan, 2017; Habibi, Rahmati \& Karimi, 2018; Atan \& Arslanturk, 2012; Li, Jin \& Shi, 2017). Besides, contribution of tourism to global economic growth cannot be overemphasized. For instance, in 2011, the tourism sector contributed 9\% to global Gross Domestic Product (GDP), an equivalent of about 6 billion US Dollars (WTTC, 2011) and accounted for about $10 \%$ of the world's GDP in 2014 (WTTC, 2015). Similarly, in 2017 the sector contributed to as much as about 8,272.3 billion US Dollars, representing 10.4\% of global GDP (WTTC, 2018). Worthy of mention here is that even with geopolitical and slow economic growth experienced in developing and some developed countries of the world, the contribution of tourism sector to global GDP is still expected to rise by $3.8 \%$ annually to $12,450.1$ billion US Dollars in 2028 (WTTC, 2018). In addition to contributing to global GDP, tourism sector has contributed in enhancing economic activities in diverse ways such as generating employment opportunities in tourist centres, income generation, foreign exchange earnings, boosting investment and stimulating other sectors of an economy (Croes, 2006; Koens \& Wood, 2017; Schubert, Brida, \& Risso, 2010).

Despite geopolitical agitations and moderate economic growth experienced by the developing and developed countries, lately the travel and tourism industry has witnessed a monumental increase globally (Fahimi, Akadiri Seraj \& Akadiri, 2018). The ind ustry is the world's largest service industry and one of the fastest growing sectors, accounting for over one-third of the value of total trade worldwide services (Atan \& Arslanturk, 2012). Over the last several decades, the total growth of the industry has been remarkable. For instance, in 2013, international tourist arrivals increased by 5\%, international tourism receipts increased by $7.5 \%$ (UNWTO, 2014) and the industry is expected to grow by an average rate of $4 \%$ annually over the next ten years (WTTC, 2011). Global receipts from tourism rose from 495 billion US Dollars in 2000 to 1.22 trillion US Dollars in 2016 (UNWTO, 2017). In terms of growth rate, the tourism and travel sector grows at a faster rate (of $4 \%$ annually) than other sectors such as transportation, financial and manufacturing sectors (WTTC, 2015) and by 2030, the total number of arrival of tourists is expected to grow to 1.8 billion (UNWTO, 2014). This speedy growth rate experienced by the tourism and travel sector over the years is attributable to several factors (both natural and manmade) that attract tourist across the world.

Africa is richly endowed with diverse natural resources which include historical spots, safaris, deserts, cultural heritage, serene environment, etc., that have attracted and still have high potentials for attracting more tourists from all over the world. Thus, this study aims at modelling the nexus between economic growth and tourism in Africa. We therefore contribute to hitherto stock of knowledge in four ways as follows. First, we examine how tourism impacts on economic growth in Africa in the short and long run. Secondly, we investigate if the short and long run impacts of tourism on economic growth in the five sub-regions of Africa differ from that of Africa. Thirdly, we examine the causal relationship between tourism and economic growth in Africa. Furthermore, we investigate whether the causal relationship between tourism and economic growth in the five region of Africa differ from that of Africa.

The remainder of this paper is organized as follows: section two is literature review, section three is methodology, section four is discussion of findings while section five is summary and conclusion.

\section{EMPIRICAL REVIEW}

The relationship between tourism and economic growth has attracted the attention of many scholars in recent years. Thus, researchers across the world have employed various methodologies to determine this relationship and have arrived at a number of conclusions. Four hypotheses have emerged from the findings of these studies in the literature viz: The Tourism-Led Economic Growth (TLEG), Economic-Driven Tourism Growth (EDTG), Feedback and Neutrality hypotheses. We review some of the studies on the relationship between tourism and economic growth as follow. 
Jalil, Mahmood and Idrees (2013) investigate the long run relationship between tourism and economic growth in Pakistan using annual data from 1972-2011. They utilize Autoregressive Distributed Lag (ARDL) and Granger causality test and establish that there is a one-way causality from tourism to economic growth. This finding is supported by Kumar and Stauvnermann (2016) who use same methodology and data frequency for the period 1978-2014 to estimate the long and short run elasticity of output with respect to tourism in Sri Lanka. Similarly, Tang and Tan (2015) apply Vector Error Correction Model (VECM) and Granger causality test to annual data that spans from 1975-2011 to verify the validity of the tourism-led growth hypothesis in Malaysia. Their findings reveal a unidirectional causality from tourism to economic growth.

Furthermore, in order to re-investigate the long-run co-movements and causal relationships between tourism development and economic growth for 55 Organisation for Economic Cooperation and Development (OECD) and non-OECD countries, Lee and Chang (2008) apply Fully-Modified Ordinary Least Square (FMOLS) and Granger causality test to annual data spanning from 19902002. They establish that in the long run, there is unidirectional causal relationship from tourism development to economic growth in OECD countries. This finding is corroborated by Chou (2013) who use Granger causality test to examine the causal relationships between tourism spending and economic growth in 10 transition countries from 1988-2011 and finds that growth hypothesis holds for Cyprus, Latvia and Slovakia. Fahimi, et al. (2018) examine whether the tourism-induced growth hypothesis of the period 1995-2015 is still valid in the case of 11 Micro States using Granger causality test. Their result shows an evidence of tourism-induced growth over the sampled period.

By means of quarterly data that span from 1975Q1-2001Q1, Oh (2005) seeks to contribute in resolving the question on the tourism-led growth hypothesis in Korea. He applies Granger causality test and a bivariate Vector Autoregressive (VAR) Model and confirms the existence of a one-way causal relationship of economic driven tourism growth. Antonakakis, Dragouni, Eeckels and Filis (2016) examine the dynamic links between tourism and economic growth by means of Panel Vector Autoregressive (VAR) and annual data for the period 1995-2011 for 98 countries and find a long run causality from economic growth to tourism. More so, Chou (2013) confirms that economic driven tourism growth holds for Czech Republic and Poland. On the other hand, findings of Zhang and Gao (2016) who use annual data from 1995-2011 to explore the effects of international tourism on China's economic growth, energy consumption and environmental pollution by means of FMOLS and panel Granger causality suggests that tourism induced economic growth hypothesis does not exist in central China and the hypothesis is weakly supported in Eastern and Western China.

In order to evaluate whether expansion of the tourism industry has contributed to Thailand's economic growth and vice versa, Chulaphan and Barahona (2017) use monthly data from January 2008 to November 2015. They employ Granger causality test and establish a bidirectional relationship between tourism and economic growth. Also, Antonakakis, Dragouni and Filis (2015) investigate the link between tourism growth and economic growth for the European countries with monthly data covering 19950-2012 using the Spillover Index. They confirm both tourism led economic growth and economic led tourism growth. These findings are similar to the findings of Dogru and Bulut (2017) who examine the causal relationships between tourism development and economic growth using annual data from 1996-2014 for 7 European countries and find a bidirectional causality between growth in tourism receipts and economic growth. Also, this finding is supported by Antonakakis, et al. (2016) in the short run for 98 countries of the world and Chou (2013) who establish that the feedback hypothesis holds for Estonia and Hungary.

In investigating the time-varying causal links between the real tourism receipts and real GDP in Turkey with annual data that spans from 1963-2006, Arslanturk, Balcilar and Ozdemir (2011) use VECM and Granger causality test and observe that there is no causality between tourism and GDP. Likewise, Chou (2013) establish that there is no causality between tourism spending and economic growth for Bulgaria, Romania and Slovenia. The study aims at examining the causal relationships between tourism spending and economic growth in 10 transition countries and utilizes Granger causality test and annual data that covers the period 1988-2011.

Having searched through the literature, to the best of our knowledge, no study has investigated the short and long run impact of tourism on economic growth in Africa and in the sub-regions of Africa. Besides, the causal relationships between tourism and economic growth in Africa and in the sub-regions of Africa have not been ascertained by the earlier studies. This study therefore fills these gaps that existed in the literature, thereby widening the boundary of knowledge.

\section{METHODOLOGY}

\section{The Model}

We model economic growth and tourism nexus in Africa. To achieve this objective, we employ symmetric panel Autoregressive Distributed Lag (ARDL) model developed by Shin and Greenwood-Nimmo (2014) and panel non-Granger causality test developed by Dumitrescu and Hurlin (2012). In this study, we utilize the symmetric panel ARDL to investigate the short and long run impact of tourism on economic growth, while the granger non causality is employed to establish the causal relationship between tourism and economic growth in Africa as well as in the sub regions of the continent. The symmetric panel ARDL model is based on Equation 1. 
Where $p$ is lag of the explained variable (economic growth) proxied with nominal GDP in US Dollar, while $q$ denotes lag of the explanatory variable, which in this study is tourism proxied with international tourism receipts in current US Dollars. Thus, Equation 2 is the symmetric Panel ARDL.

$$
\begin{aligned}
\Delta \ln G D P_{t}= & \phi_{0 i}+\phi_{1 i} \ln G D P_{i, t-1}+\phi_{2 i} \ln T R M_{i, t-1}+\sum_{m=1}^{M} \sigma_{i m} \Delta \ln G D P_{i, t-m}+\sum_{n=0}^{N} \rho_{i n} \Delta \ln T R M_{i, t-n} \\
& +\mu_{i}+\varepsilon_{i t} \\
& i=1,2,3, \ldots \ldots \ldots \ldots \ldots \ldots . ., N ;
\end{aligned}
$$

In Equation 2, $\ln G D P_{i, t}$ denotes $\log$ of economic growth over period $t$ for every $i$ unit, $\ln T R M_{i, t}$ indicates $\log$ of tourism for every $t$ for each $i$ unit, $i$ signifies the units of sample and $\mu_{i}$ represents group specific effect. We compute the long run coefficient of elasticity, otherwise called the slope coefficient for every cross-section. However, since in the long run $\Delta \ln G D P_{i, t-m}$ and also $\Delta \ln T R M_{i, t-n}$ vanish, we arrive at the long run coefficient of elasticity as follows $-\frac{\phi_{2 i}}{\phi_{1 i}}$. In Equation 2 , the short run estimate for tourism is $\rho_{i n}$. We restate Equation 2 to capture the Error Correction Term $(E C T)$, hence, Equation 3.

$$
\Delta \ln G D P_{t}=\sum_{m=1}^{M} \sigma_{i m} \Delta \ln G D P_{i, t-m}+\sum_{n=0}^{N} \rho_{i n} \Delta \ln T R M_{i, t-n}+\lambda_{i} \Psi_{i, t-1}+\mu_{i}+\varepsilon_{i t}
$$

In Equation 3, the true ECT for every unit is defined as $\Psi_{i, t-1}=\ln G D P_{i, t-1}-\gamma_{0 i}-\gamma_{1 i} \ln T R M_{i, t-1}$, while the Error Correction Coefficient (ECC), which is the speed of adjustment (i.e., the rate at which the previous year's deviation from the long run equilibrium is corrected in the current year) for every unit is $\lambda_{i}$. This speed of adjustment for every unit is equivalent to the coefficient of long run term of economic growth in Equation 2. To further make ECT clear, $\gamma_{0 i}$ and $\gamma_{1 i}$ are respectively estimated as follows $-\frac{\phi_{0 i}}{\phi_{1 i}}$ and $-\frac{\phi_{2 i}}{\phi_{1 i}}$. This completes the symmetric ARDL model estimated for the study.

\section{Techniques of Estimation}

We apply the most commonly used techniques of estimation, i.e., the Pooled Mean Group (PMG) and the Mean Group (MG) estimators. PMG and MG estimators are appropriate for estimating dynamic heterogeneous panel models. It is important we distinguish between these two techniques of estimating dynamic heterogeneous panel models. The MG estimator depends on time series regressions with large cross-sections (i.e., large N) and is based on the average (mean) of the estimated parameters. On the other hand, PMG estimator pools as well as takes the average of the parameters (coefficients) estimated (Blackburne \& Frank, 2007). After estimating the MG and the PMG, we carry out hausman test. This test is necessitated by the fact that it establishes whether or not there exists symmetric difference between these two estimators (MG and PMG) (Salisu \& Isah, 2017). Based on the hausman test outcome, we select the efficient estimator for establishing tourism-economic growth nexus in Africa.

\section{Granger Causality}

We authenticate the causal relationship between tourism and economic growth in Africa based on Granger non-causality test developed by Dumitrescu and Hurlin (2012). The test which is developed to test for Granger non-causality in heterogeneous panel data models has some advantages, some of which are: it accounts for dimensions of heterogeneity in panel data, i.e., heterogeneity of causal relationships and the causality of the regression model; it accounts for cross-sectional dependence as well as it is appropriate for sample with both short and long T and N. To take cross-sectional dependencies into account, Dumitrescu and Hurlin (2012) developed a block bootstrap simulation approach to group mean Wald-Statistic (on which the test is based). Thus, suppose that for 
every $i=1,2$, $N$ and $t=1,2$, $T$, the Granger non-causality models for this study are stated as follows.

$$
\begin{aligned}
& G D P_{i, t}=\lambda_{i}+\sum_{l=1}^{L} \phi_{i}^{(k)} G D P_{i, t-l}+\sum_{m=1}^{M} \varphi_{i}^{(k)} \operatorname{TRM}_{i, t-m}+\varepsilon_{i, t} \\
& T R M_{i, t}=\gamma_{i}+\sum_{m=1}^{M} \varphi_{i}^{(k)} T R M_{i, t-m}+\sum_{l=1}^{L} \phi_{i}^{(k)} G D P_{i, t-l}+\varepsilon_{i, t}
\end{aligned}
$$

Individual effects $\left(\lambda_{i}\right.$ and $\left.\gamma_{i}\right)$ in Equations 4 and 5 are fixed in time dimension, the lag orders, i.e., $L$ and $M$ are assumed to be identical for all cross-sections, the autoregressive parameters and the slope of regression coefficient are constant in time. However, the Autoregressive parameters and the regression coefficients slopes differ across groups. Equations 4 and 5 are fixed coefficients models with fixed individual effects and are based on the following fundamental assumptions. For every cross-section, i.e., $i=1, \ldots \ldots \ldots . . . . . ., N$, the individual residuals $\varepsilon_{i, t}, \forall t=1, \ldots \ldots \ldots \ldots, T$ are independently and normally distributed with $E\left(\varepsilon_{i, t}\right)=0$ and limited heterogeneous variances equations, that is $E\left(\varepsilon_{i, t}^{2}\right)=\sigma_{\varepsilon, i}^{2}$. Individual residuals of Equations 4 and 5, i.e., $\varepsilon_{i}=\left(\varepsilon_{i, 1}, \ldots \ldots \ldots, \varepsilon_{i, T}\right)^{\prime}$ are independently distributed across groups. This means that $E\left(\varepsilon_{i, t} \varepsilon_{j, r}\right)=0, \forall i \neq j$ and $\forall(t, r)$. Furthermore, both the individual variables $\left(\ln G D P_{i}\right.$ and $\left.\ln T R M_{i}\right)$ in the models are covariance stationary with $E\left(\ln T R M_{i, t}^{2}\right)<\infty$ and $E\left(\ln G D P_{i, t}^{2}\right)<\infty$. In addition to these assumptions, $E\left(\ln T R M_{i, t} \ln T R M_{i, v}\right)$, $E\left(\ln G D P_{i, t} \ln G D P_{i, v}\right)$, and $E\left(\ln T R M_{i, t} \ln G D P_{i, v}\right)$, are only function of the difference $t-v$, with, $\ln G D P_{i, t}$ and $\ln T R M_{i, t}$ being independent of $t$.

Allowing for a sub-group or subgroups of individuals for which there is no causal relation and a subgroup of individuals for which variables granger cause each other, the null hypothesis of the Homogenous Non-Causality (HNC) proposed by Dumistrescu and Hurlin (2012) is given as

$$
H_{0}: \varphi_{i}=0 \quad \forall i=1, \ldots \ldots \ldots . ., N
$$

Following Dumistrescu and Hurlin (2012), we assume that not all individual vector of $\varphi_{i}$ are to be equal to zero (i.e., no causality assumption) in stating the alternative hypothesis. Thus, under the $H_{1}$, there are $N_{1}<N$ individual processes with no causality from one variable to another. Thus, Equation 7 states the alternative hypothesis of the test.

$$
H_{1}: \varphi_{i}=0 \quad \forall i=1,2, \ldots \ldots \ldots \ldots, N_{1}, \quad \varphi_{i} \neq 0 \quad \forall i=N_{1}+1, N_{1}+2, \ldots \ldots \ldots, N
$$

$N_{1}$ in Equation 7 satisfies the condition $0 \leq N_{1} / N<1$. This implies that if $N_{1}=N$, there exists no causality between the series in the panel. In contrasts, if $N_{1}=0$, there exists causality for all the individuals in the series. In the case of Equation 4, if we accept the null hypothesis, we conclude that for all the panel units, tourism does not granger cause economic growth. Similarly, for Equation 5, if we accept the null hypothesis, the conclusion is economic growth does not granger cause tourism. It therefore signifies that in order to confirm that tourism granger causes economic growth or economic growth granger causes tourism, we have to reject the null hypothesis of Equations 4 and 5. Since the causality test is based on the average of Wald statistics of the test of non-causality for $i=1,2$, .., $N$, Equation 8 state the average Wald statistics thus:

$W_{N, T}^{H n c}=\frac{1}{N} \sum_{i=1}^{N} W_{i, T}$

Equation 8 is the average statistic associated with the null Homogenous Non-causality hypothesis. Hnc is homogenous non-causality, $W_{i, T}$ represents Wald statistics for every $i^{\text {th }}$ cross-section units, and corresponds to the individual test of the null hypothesis, i.e., $H_{0}: \varphi_{i}=0$ 


\section{Data}

The study covers Africa and is based on annual data that spans from 1995-2016. We select Forty-Eight African countries for the study. Selection of these countries and the choice of the period for the study is strictly based on availability of data on the variables used for the study, i.e., tourism and economic growth. We proxy economic growth with nominal GDP in US Dollar, while tourism is proxied with international tourism receipts in current US Dollar. To interpret our findings in terms of elasticity, we transform the variables (tourism and economic growth) to log form. Data on these variables were sourced from the 2017 World Bank Development Indicators. Furthermore, the study is based on balanced panel data. Table 1 presents the African countries used for the study based on sub-regions.

\section{TABLE 1: CLASSIFICATION OF COUNTRIES USED FOR THE STUDY BASED ON FIVE SUB-REGIONS OF AFRICA}

\begin{tabular}{|c|c|c|c|c|}
\hline Central Africa & South Africa & North Africa & West Africa & East Africa \\
\hline Cameroon & Angola & Algeria & Benin & Burundi \\
\hline Central African Republic & Botswana & Egypt & Burkina Faso & Comoros \\
\hline Democratic Republic of Congo & Lesotho & Libya & Cote Di’voir & Djibouti \\
\hline Congo republic & Malawi & Morocco & Gambia & Eritrea \\
\hline Gabon & Mozambique & Tunisia & Ghana & Ethiopia \\
\hline \multirow[t]{9}{*}{ Sao Tome and Principe } & Namibia & & Guinea & Kenya \\
\hline & Swaziland & & Guinea-Bissau & Madagascar \\
\hline & Zambia & & Liberia & Mauritius \\
\hline & Zimbabwe & & Mali & Rwanda \\
\hline & South Africa & & Niger & Seychelles \\
\hline & & & Nigeria & Sudan \\
\hline & & & Senegal & Tanzania \\
\hline & & & Sierra Leone & Uganda \\
\hline & & & Togo & \\
\hline
\end{tabular}

\section{RESULTS AND DISCUSSIONS}

Table 2 is the summary statistics and reveals that the average value of economic growth in Africa is 22.6272, while that of tourism is 18.2324; affirming that the economy of Africa grows faster than growth in tourism. Equally, minimum values of economic growth and tourism in Africa are respectively 18.0954 and 1.6090, while their respective maximum values are 27.0663 and 23.2801 . With regard to variability, Table 2 upholds that tourism is more variable than economic growth in Africa; i.e., economic growth is more stable (less volatile) than tourism. Turning to sub-regions of the continent, West Africa has the highest economic growth; it stood at 27.0663. In contrast, Central Africa has the least economic growth (18.5898). In terms of average economic growth, Northern region of the continent has the highest value, while Eastern region has the least value. This suggests that the economy of Northern Africa grows faster than the economy of the other sub-regions of the continent. Similarly, Northern Africa has the greatest average value of tourism. In contrast, central region has the least average value, indicating that whereas the Northern sub-region does attract more tourists than the other sub-regions do, the central region is least attractive to tourists. In terms of stability or otherwise of economic growth and tourism in the regions of Africa, economic growth is most unstable in the Western region and most stable in the Northern part. Correspondingly, tourism is most unstable in the Eastern and least variable in the Central regions of the continent. 
TABLE 2: DESCRIPTIVE STATISTICS

\begin{tabular}{|c|c|c|c|c|c|c|c|c|c|c|c|c|}
\hline & \multicolumn{2}{|c|}{ All Countries } & \multicolumn{2}{|c|}{ Central Africa } & \multicolumn{2}{|c|}{$\begin{array}{l}\text { Eastern } \\
\text { Africa }\end{array}$} & \multicolumn{2}{|c|}{$\begin{array}{l}\text { Northern } \\
\text { Africa }\end{array}$} & \multicolumn{2}{|c|}{$\begin{array}{l}\text { Southern } \\
\text { Africa }\end{array}$} & \multicolumn{2}{|c|}{$\begin{array}{l}\text { Western } \\
\text { Africa }\end{array}$} \\
\hline & $\begin{array}{l}\operatorname{lnGD} \\
\mathrm{P}\end{array}$ & $\begin{array}{l}\operatorname{lnTR} \\
\mathrm{M}\end{array}$ & $\begin{array}{l}\operatorname{lnGD} \\
\mathrm{P}\end{array}$ & $\begin{array}{l}\ln \mathrm{TR} \\
\mathrm{M}\end{array}$ & $\begin{array}{l}\operatorname{lnGD} \\
\mathrm{P}\end{array}$ & $\begin{array}{l}\operatorname{lnTR} \\
\mathrm{M}\end{array}$ & $\begin{array}{l}\operatorname{lnGD} \\
\mathrm{P}\end{array}$ & $\begin{array}{l}\operatorname{lnTR} \\
\mathrm{M}\end{array}$ & $\begin{array}{l}\operatorname{lnGD} \\
\mathrm{P}\end{array}$ & $\begin{array}{l}\operatorname{lnTR} \\
\mathrm{M}\end{array}$ & $\begin{array}{l}\ln G D \\
P\end{array}$ & $\begin{array}{l}\ln \mathrm{TR} \\
\mathrm{M}\end{array}$ \\
\hline Mean & $\begin{array}{l}22.62 \\
72\end{array}$ & $\begin{array}{l}18.23 \\
24\end{array}$ & $\begin{array}{l}22.32 \\
09\end{array}$ & $\begin{array}{l}17.24 \\
64\end{array}$ & $\begin{array}{l}22.17 \\
57\end{array}$ & $\begin{array}{l}17.41 \\
15\end{array}$ & $\begin{array}{l}24.90 \\
24\end{array}$ & $\begin{array}{l}20.71 \\
24\end{array}$ & $\begin{array}{l}22.93 \\
88\end{array}$ & $\begin{array}{l}18.98 \\
44\end{array}$ & $\begin{array}{l}22.26 \\
55\end{array}$ & $\begin{array}{l}17.99 \\
44\end{array}$ \\
\hline Max & $\begin{array}{l}27.06 \\
63\end{array}$ & $\begin{array}{l}23.33 \\
58\end{array}$ & $\begin{array}{l}24.28 \\
01\end{array}$ & $\begin{array}{l}20.26 \\
12\end{array}$ & $\begin{array}{l}25.29 \\
96\end{array}$ & $\begin{array}{l}21.54 \\
7\end{array}$ & $\begin{array}{l}26.53 \\
08\end{array}$ & $\begin{array}{l}23.33 \\
58\end{array}$ & $\begin{array}{l}26.75 \\
61\end{array}$ & $\begin{array}{l}23.13 \\
94\end{array}$ & $\begin{array}{l}27.06 \\
63\end{array}$ & $\begin{array}{l}20.86 \\
65\end{array}$ \\
\hline Min & $\begin{array}{l}18.09 \\
54\end{array}$ & $\begin{array}{l}1.609 \\
0\end{array}$ & $\begin{array}{l}18.58 \\
98\end{array}$ & $\begin{array}{l}11.51 \\
29\end{array}$ & $\begin{array}{l}19.13 \\
29\end{array}$ & $\begin{array}{l}1.609 \\
0\end{array}$ & $\begin{array}{l}23.61 \\
54\end{array}$ & $\begin{array}{l}14.91 \\
41\end{array}$ & $\begin{array}{l}20.46 \\
94\end{array}$ & $\begin{array}{l}15.25 \\
06\end{array}$ & $\begin{array}{l}18.71 \\
93\end{array}$ & $\begin{array}{l}13.72 \\
23\end{array}$ \\
\hline $\begin{array}{l}\text { Std. } \\
\text { Dev. }\end{array}$ & $\begin{array}{l}1.720 \\
2\end{array}$ & $\begin{array}{l}3.100 \\
1\end{array}$ & $\begin{array}{l}1.772 \\
4\end{array}$ & $\begin{array}{l}1.484 \\
4\end{array}$ & $\begin{array}{l}1.541 \\
0\end{array}$ & $\begin{array}{l}4.945 \\
3\end{array}$ & $\begin{array}{l}0.708 \\
1\end{array}$ & $\begin{array}{l}1.965 \\
6\end{array}$ & $\begin{array}{l}1.464 \\
9\end{array}$ & $\begin{array}{l}1.704 \\
0\end{array}$ & $\begin{array}{l}1.590 \\
1\end{array}$ & $\begin{array}{l}1.492 \\
6\end{array}$ \\
\hline $\begin{array}{l}\text { No. of } \\
\text { Obs. }\end{array}$ & 1,056 & 1,056 & 132 & 132 & 286 & 286 & 110 & 110 & 220 & 220 & 308 & 308 \\
\hline
\end{tabular}

We employ four groups of unit root tests to establish the stationarity features of tourism and economic growth. Categorization of the unit root tests is purely based on their respective null hypotheses. Null hypothesis of the first group is unit root with common process and consists of Breitung (2000), Harris and Tzavalis (1999), and Levin, Lin and Chu (2002) tests. Null hypothesis of the second group is unit root with individual unit root process and comprises Im, Pesaran and Shin (2003) and Maddala and $\mathrm{Wu}(1999)$ tests. Null hypothesis of the third category, which consists of Pesaran (2007) test is unit root in the presence of crosssectional dependence. The fourth class consists of Hadri (2000) Lagrange Multiplier test and the null hypothesis is unit root with common unit root test. We employ these four categories of unit root tests to ensure robustness of the test. Results of all the unit root tests reported in Table 3 confirm that tourism and economic growth are not spurious, since they are stationary either at level or at their first difference. 


\begin{tabular}{|c|c|c|c|c|c|c|c|c|c|c|c|c|}
\hline & \multicolumn{2}{|c|}{ All Countries } & \multicolumn{2}{|c|}{ Central Africa } & \multicolumn{2}{|c|}{ Eastern Africa } & \multicolumn{2}{|c|}{ Northern Africa } & \multicolumn{2}{|c|}{ Southern Africa } & \multicolumn{2}{|c|}{ Western Africa } \\
\hline \multicolumn{13}{|c|}{ Null hypotheis: unit root with common process } \\
\hline & $\ln G D P_{t}$ & $\ln T R M_{t}$ & $\ln G D P_{t}$ & $\ln T R M_{t}$ & $\ln G D P_{t}$ & $\ln T R M_{t}$ & $\ln G D P_{t}$ & $\ln T R M_{t}$ & $\ln G D P_{t}$ & $\ln T R M_{t}$ & $\ln G D P_{t}$ & $\ln T R M_{t}$ \\
\hline $\begin{array}{l}\text { Levin, Lin } \\
\& \text { Chu t* }\end{array}$ & $-1.3940 *^{\mathrm{x}}$ & $-3.2922^{*} * *^{\mathrm{x}}$ & $2.9226 * * * y$ & $-\overline{4.6416 * * * y}$ & $-\overline{2.0365 * * \mathrm{y}}$ & $\begin{array}{l}- \\
8.0155 * * *\end{array}$ & $2.1345^{* * y}$ & $-7.7319 * *^{x}$ & $-1.4585^{* x}$ & $\begin{array}{l}- \\
2.7567 * * *\end{array}$ & 6.3148***y & $-2.0826^{* x}$ \\
\hline $\begin{array}{l}\text { Breitung t- } \\
\text { stat. }\end{array}$ & $\begin{array}{l} \\
12.6959 * * * \\
\mathrm{y}\end{array}$ & $-\overline{16.2755 * * * \mathrm{y}}$ & $-4.2984 * * *$ & $\begin{array}{l}- \\
6.7667 * * * y\end{array}$ & $\begin{array}{l} \\
4.9999 * * * \\
\mathrm{y}\end{array}$ & $\begin{array}{l}- \\
8.6401 * * *\end{array}$ & $-\overline{4.8343 * * *}$ & $\begin{array}{l}- \\
6.5558 * * * \\
y\end{array}$ & $\begin{array}{l}- \\
4.9615 * * * \\
\mathrm{x}\end{array}$ & $\begin{array}{l}- \\
6.4767 * * * \\
\mathrm{y}\end{array}$ & $9.8428 * * * \mathrm{y}$ & $\begin{array}{l}- \\
8.3306 * * * \\
y\end{array}$ \\
\hline $\begin{array}{l}\text { Harris- } \\
\text { Tzavalis } \\
\text { rho }\end{array}$ & $\begin{array}{l}- \\
0.0100 * * * y\end{array}$ & $0.7880 * * *^{\mathrm{X}}$ & $0.0849 * * * \mathrm{y}$ & $0.3631 * * *^{x}$ & $\begin{array}{l}0.1178 * * * \\
\mathrm{y}\end{array}$ & $\begin{array}{l}- \\
0.2793 * * * \\
\mathrm{y}\end{array}$ & $\begin{array}{l}- \\
0.1581 * * * \\
\mathrm{y}\end{array}$ & $\begin{array}{l}0.0055 * * * \\
\mathrm{y}\end{array}$ & $\begin{array}{l}0.1897 * * * \\
\mathrm{y}\end{array}$ & $\begin{array}{l}- \\
0.3449 * * * \\
\mathrm{y}\end{array}$ & $0.1333 * * * y$ & $\begin{array}{l}0.7718 * * * \\
\mathrm{x}\end{array}$ \\
\hline \multicolumn{13}{|c|}{ Null hypothesis: unit root with individual unit root process } \\
\hline $\begin{array}{l}\text { Im, Pesaran } \\
\text { \& Shin W } \\
\text { Stat. }\end{array}$ & $\begin{array}{l}- \\
12.4290 * * * \\
\mathrm{y}\end{array}$ & - $16.7304 * * * \mathrm{y}$ & $4.0649 * * * \mathrm{y}$ & - $6.7004 * * * y$ & $\begin{array}{l}- \\
6.3097 * * * \\
\mathrm{y}\end{array}$ & $\begin{array}{l}- \\
8.5850 * * * \\
\mathrm{y}\end{array}$ & $\begin{array}{l}- \\
3.7024 * * * \\
\mathrm{y}\end{array}$ & $\begin{array}{l}- \\
4.7751 * * * \\
\mathrm{y}\end{array}$ & $\begin{array}{l}- \\
\mathrm{y} .0956 * * *\end{array}$ & $\begin{array}{l}- \\
\mathrm{y}\end{array}$ & $6.8055 * * * \mathrm{y}$ & $\begin{array}{l}- \\
8.8014 * * * \\
\mathrm{y}\end{array}$ \\
\hline $\begin{array}{l}\text { ADF } \\
\text { Fisher Chi- } \\
\text { quare }\end{array}$ & $124.5521 * *$ & $\begin{array}{l}138.5200 * * \\
* x\end{array}$ & $\begin{array}{l}32.9217 * * * \\
\mathrm{y}\end{array}$ & $\begin{array}{l}36.1798 * * * \\
\mathrm{y}\end{array}$ & $30.2418^{\mathrm{y}}$ & $\begin{array}{l}39.6294 * * \\
\mathrm{y}\end{array}$ & $11.4654^{\mathrm{y}}$ & $11.8937^{\mathrm{x}}$ & $11.9476^{\mathrm{y}}$ & $29.8589 * \mathrm{y}$ & $\begin{array}{l}50.6493 * * * \\
\mathrm{y}\end{array}$ & $32.1917^{y}$ \\
\hline $\begin{array}{l}\text { Pesaran } \\
\text { CD test }\end{array}$ & $-1.334^{\mathrm{x}}$ & $-1.400^{\mathrm{x}}$ & $-2.774 * * * y$ & $-3.011 * * *^{\mathrm{x}}$ & $-1.904^{\mathrm{y}}$ & $2.922 * * * y$ & $3.520 * * * y$ & $-2.676^{* * x}$ & $2.489 * * *^{\mathrm{x}}$ & $0.929^{\mathrm{x}}$ & $-1.961^{\mathrm{y}}$ & $-1.327^{y}$ \\
\hline \multicolumn{13}{|c|}{ Null hypothesis: no unit root with common unit root process } \\
\hline $\begin{array}{l}\text { Hadri Z- } \\
\text { stat }\end{array}$ & $-0.2441^{\mathrm{y}}$ & $-4.2628^{\mathrm{y}}$ & $2.6246^{* * * y}$ & $-2.2275^{y}$ & $1.2908^{y}$ & $-2.5182^{y}$ & $-0.8996^{\mathrm{y}}$ & $\begin{array}{l}0.0021 * * * \\
\mathrm{y}\end{array}$ & $0.9511^{\mathrm{y}}$ & $-2.067^{y}$ & $-0.0678^{y}$ & $-1.8666^{y}$ \\
\hline $\begin{array}{l}\text { No. of } \\
\text { cross- } \\
\text { sections }\end{array}$ & 48 & 48 & 6 & 6 & 13 & 13 & 5 & 5 & 10 & 10 & 14 & 14 \\
\hline $\begin{array}{l}\text { No. of } \\
\text { periods }\end{array}$ & 22 & 21 & 21 & 21 & 21 & 21 & 21 & 21 & 22 & 22 & 22 & 22 \\
\hline $\begin{array}{l}\text { No. } \\
\text { observation } \\
\text { S }\end{array}$ & 760 & 760 & 126 & 126 & 273 & 273 & 105 & 105 & 160 & 160 & 308 & 308 \\
\hline
\end{tabular}

Note: $* * *, * *$ and $*$ denote statistically significant at $1 \%, 5 \%$ and $10 \%$ respectively, while ${ }^{\mathrm{x}}$ and ${ }^{\mathrm{y}}$ signify model at level and first difference respectively. 
Mean Group (MG) and Pooled Mean Group (PMG) were employed to estimate Equations 2 and 3, afterwards we subject the estimated results to hausman test in oder to choose the efficient estimator. We choose the efficient estimator based on the acceptance (which suggests that PMG is the efficient estimator) or otherwise (suggesting that MG is the efficient estimator) of the null hypothesis of the test. As the decision rule suggests, if the null hypothesis is not rejected, we accept and report the PMG estimator, else, we accept and report the MG as the efficient estimator (as suggested by the alternative hypothesis of the test). Table 4 reports the estimates of both the MG and PMG estimators. The hausman test statistics and their respective probability values suggest that for Africa, the Pooled Mean Group (PMG) is preferred to the Mean Group (MG). That is to say, of the two estimators, PMG is the efficient. Similarly, the hausman test suggests that the PMG is preferred in the Northern, Southern and the Western regions of Africa. However, for Central and Eastern Africa, the test suggests that the MG is robust. Thus, we report and interpret our results based on outcome of the hausman test.

Table 4 reports estimates of Equations 2 and 3. We find an evidence of long run convergence between economic growth and tourism in Africa and in all the sub-regions of the continent. Coefficients of their respective ECT have the correct sign, correct magnitude and are all statistically significant at $1 \%$ level. As Table 4 affirms, certain percentage (i.e., not 100\%) of previous year's short run deviation from equilibrium of the variables (tourism and economic growth) in Africa and in sub-regions of Africa is corrected in the current year until the long run equilibrium is attained. Furthermore, Table 4 confirms that in Africa, the long run impact on economic growth of tourism deviates significantly from the short run impact. While in the short run tourism stifles economic growth insignificantly, in the long run it is indispensable for economic growth. In terms of size, magnitude of the long run impact is much greater than the magnitude of the short run impact. All else constant, a $1 \%$ increase in tourism weakens economic growth by $0.0024 \%$ (not statistically significant) in the short run, however, in the long run it spurs economic growth by $0.7540 \%$ and is statistically significant at $1 \%$ level.

Evidence in Table 4 indicates that short run impact of tourism on economic growth in Eastern and Southern Africa does not deviate from its short run impact on economic growth in the continent. Just like in Africa, tourism has negative insignificant short run impact on economic growth in these regions; with the magnitude of the effect more in the Eastern region than in the Southern region. All else constant, in the short run if tourism rises by $1 \%$, economic growth will decline by $0.0092 \%$ and $0.0215 \%$ in the Eastern and Southern Africa respectively (both are higher than that of Africa in terms of extent). On the other hand, the short run impact of tourism (in terms of both sign and size) on economic growth in Central, Northern and Western Africa does not follow that of Africa. Unlike in Africa, in these sub-regions, tourism boosts economic growth in the short run, however, insignificantly. Though the short run impact of tourism on economic growth in these regions is almost nonexistent, the impact is more in the Southern region than in the other two sub-regions. Table 4 reports that in the short run all else constant, a $1 \%$ improvement in tourism is accompanied by $0.0039 \%, 0.0164 \%$ and $0.0258 \%$ enhancement in economic growth in the Central, Northern and Western regions of the continent respectively.

With respect to long run, it is evident in Table 4 that while the role of tourism on economic growth in Northern, Southern and Western region does not deviate from its impact on economic growth in Africa, it differs in the Central and Eastern Africa. We find tourism to be a requisite for economic growth in Northern, Southern and Western Africa in the long run. However, in the Central and Eastern Africa, tourism is not essential for economic growth in the long run. The long run contribution of tourism to the economic growth of these regions is negligible. Ceteris Paribus, increase in economic growth that accompanies a $1 \%$ increase in tourism in Northern, Southern and Western Africa are $0.534 \%, 1.049 \%$ and $0.687 \%$ respectively and are all statistically significant at $1 \%$ level. In the Central and Eastern Africa, a percentage rise in tourism will boost economic growth by $0.0239 \%$ and $0.305 \%$ respective in the long run but are statistically insignificant. 
TABLE 4: SYMMETRIC PANEL ARDL ESTIMATES

\begin{tabular}{|c|c|c|c|c|c|c|c|c|c|c|c|c|}
\hline Variable & \multicolumn{2}{|c|}{ All Countries } & \multicolumn{2}{|c|}{ Central Africa } & \multicolumn{2}{|c|}{ Eastern Africa } & \multicolumn{2}{|c|}{ Northern Africa } & \multicolumn{2}{|c|}{ Southern Africa } & \multicolumn{2}{|c|}{ Western Africa } \\
\hline \multicolumn{13}{|l|}{ Long Run } \\
\hline & MG & PMG & MG & PMG & MG & PMG & $\mathrm{MG}$ & PMG & MG & PMG & MG & PMG \\
\hline Constant & $\begin{array}{l}5.369 * * * \\
(0.741)\end{array}$ & $\begin{array}{l}1.635 * * * \\
(0.223)\end{array}$ & $\begin{array}{l}4.661 * * * \\
(1.018)\end{array}$ & $\begin{array}{l}4.692 * * * \\
(1.201)\end{array}$ & $\begin{array}{l}5.021 * * * \\
(1.209)\end{array}$ & $\begin{array}{l}2.089 * * * \\
(0.509)\end{array}$ & $\begin{array}{l}4.410 \\
(3.140)\end{array}$ & $\begin{array}{l}3.4898 * * * \\
(0.830)\end{array}$ & $\begin{array}{l}3.921 * * * \\
(0.751)\end{array}$ & $\begin{array}{l}0.570 * * \\
(0.227)\end{array}$ & $\begin{array}{l}5.715 * * * \\
(0.705)\end{array}$ & $\begin{array}{l}1.680 * * * \\
(0.481)\end{array}$ \\
\hline $\ln T R M_{t}$ & $\begin{array}{l}0.949 \\
(0.759)\end{array}$ & $\begin{array}{l}0.754 * * * \\
(0.0527)\end{array}$ & $\begin{array}{l}0.0239 \\
(0.0444)\end{array}$ & $\begin{array}{l}0.0894 * * * \\
(0.0297)\end{array}$ & $\begin{array}{l}0.305 \\
(0.209)\end{array}$ & $\begin{array}{l}0.698 * * * \\
(0.0949)\end{array}$ & $\begin{array}{l}-2.126 \\
(2.629)\end{array}$ & $\begin{array}{l}0.534 * * * \\
(0.0907)\end{array}$ & $\begin{array}{l}1.467 \\
(0.904)\end{array}$ & $\begin{array}{l}1.049 * * * \\
(0.132)\end{array}$ & $\begin{array}{l}2.608 \\
(2.320)\end{array}$ & $\begin{array}{l}0.687 * * * \\
(0.0707)\end{array}$ \\
\hline \multicolumn{13}{|l|}{ Short Run } \\
\hline $\ln T R M_{t}$ & $\begin{array}{l}0.0123 \\
(0.0241)\end{array}$ & $\begin{array}{l}-0.0024 \\
(0.0221)\end{array}$ & $\begin{array}{l}0.0039 \\
(0.0165)\end{array}$ & $\begin{array}{l}-0.0028 \\
(0.0127)\end{array}$ & $\begin{array}{l}-0.0092 \\
(0.0633)\end{array}$ & $\begin{array}{l}-0.0270 \\
(0.0577)\end{array}$ & $\begin{array}{l}0.060 \\
(0.0691)\end{array}$ & $\begin{array}{l}0.0164 \\
(0.0731)\end{array}$ & $\begin{array}{l}7.1800 \\
0.0572)\end{array}$ & $\begin{array}{l}-0.0215 \\
(0.0497)\end{array}$ & $\begin{array}{l}0.0410 \\
(0.0272)\end{array}$ & $\begin{array}{l}0.0258 \\
(0.0230)\end{array}$ \\
\hline ECT & $\begin{array}{l}-0.349 * * * \\
(0.0324)\end{array}$ & $\begin{array}{l}-0.193 * * * \\
(0.0282)\end{array}$ & $\begin{array}{l}-0.217 * * * \\
(0.0468)\end{array}$ & $\begin{array}{l}-0.227 * * * \\
(0.0555)\end{array}$ & $\begin{array}{l}-0.344 * * * \\
(0.0448)\end{array}$ & $\begin{array}{l}-0.221 * * * \\
(0.0613)\end{array}$ & $\begin{array}{l}-0.312 * * * \\
(0.120)\end{array}$ & $\begin{array}{l}-0.2590 * * * \\
(0.0727)\end{array}$ & $\begin{array}{l}0.344 * * * \\
(0.0615)\end{array}$ & $\begin{array}{l}-0.225 * * * \\
(0.0740)\end{array}$ & $\begin{array}{l}-0.342 * * * \\
(0.0439)\end{array}$ & $\begin{array}{l}-0.180 * * * \\
(0.0518)\end{array}$ \\
\hline $\begin{array}{l}\text { Hausman } \\
\text { test } x^{2}\end{array}$ & \multicolumn{2}{|c|}{$\begin{array}{c}0.04 \\
{[0.8407]}\end{array}$} & \multicolumn{2}{|c|}{$\begin{array}{c}3.57 \\
{[0.0590]}\end{array}$} & \multicolumn{2}{|c|}{$\begin{array}{c}2.89 \\
(0.0892) \\
\end{array}$} & \multicolumn{2}{|c|}{$\begin{array}{c}0.67 \\
{[0.4124]} \\
\end{array}$} & \multicolumn{2}{|c|}{$\begin{array}{c}0.18 \\
{[0.6686]}\end{array}$} & \multicolumn{2}{|c|}{$\begin{array}{c}0.52 \\
{[0.4694]}\end{array}$} \\
\hline $\begin{array}{l}\text { No. of } \\
\text { Obs }\end{array}$ & 1008 & & 126 & 126 & 273 & 273 & 105 & & 210 & & 294 & \\
\hline $\begin{array}{l}\text { Log } \\
\text { likelihood }\end{array}$ & - & 902.1324 & - & 273.9939 & - & 311.6038 & - & 108.3969 & - & 158.0669 & - & 260.1025 \\
\hline $\begin{array}{l}\text { No. of } \\
\text { Cros- } \\
\text { Sections } \\
\end{array}$ & 48 & 48 & 6 & 6 & 13 & 13 & 5 & 5 & 10 & 10 & 14 & 14 \\
\hline No. obs. & 1008 & 1009 & 126 & 126 & 273 & 273 & 105 & 105 & 210 & 210 & 294 & 294 \\
\hline
\end{tabular}

Note: $* * *$ and $* *$ represent statistical significant at $1 \%$ and $5 \%$ levels respectively. 
In verifying the causal relationship between tourism and economic growth, we test two null hypotheses viz; tourism does not granger cause economic growth and economic growth does not granger cause tourism. Rejection of the null hypothesis confirms that tourism/economic growth granger causes economic growth/tourism. Results reported in Table 5 demonstrate that in Africa, economic growth granger causes tourism and tourism in turn granger causes economic growth - bidirectional causality. This corroborates the findings of Antonakakis, et al. (2016) in 98 countries, Dogru and Bulut (2017) in 7 European countries and Antonakakis, et al. (2015) in the Europeans countries. Similarly, in Central Africa, East Africa and North Africa, economic growth granger causes tourism and vice versa - bidirectional causality. This implies that inbound tourism promotes economic growth in Africa, Central, Eastern and Northern Africa and economic growth in turn boosts tourism. Also, it suggests that tourism influences economic growth and economic growth brings about increase in the number of inbound tourists in Africa and in those sub-regions. It therefore means that in Africa and in these sub-regions of the continent, policies that promote inbound tourism such as improving the state of transportation, infrastructure, reducing or subsidizing visa fees to the regions, quality and accessible telecommunications, waiving visa fees to the region, shortening the length of period in the process of acquiring visas, airport security, etc., are good for boosting economic growth. However, for North and West Africa, one-way causality is confirmed from tourism to economic growth and from economic growth to tourism respectively. In other words, Tourism-Led Economic Growth (TLEG) hypothesis is confirmed in North Africa while Economic-Driven Tourism Growth (EDTG) is confirmed in west Africa. In North Africa, the causality results suggest that policies that promote tourism will derive economic growth, while the reverse is not the case. Furthermore, the results suggest that if inbound tourism should be enhanced in the region, other policies and not economic growth boosting policies should be pursued. On the other hand, in West Africa, economic growth policies will promote inbound tourism. In this region, growth in the economy of the region attracts tourists. Thus, if economic growth is stimulated in the region, there will be a rise in inbound tourism. 
TABLE 5: GRANGER NON-CAUSALITY RESULTS

\begin{tabular}{|c|c|c|c|c|c|c|c|c|c|c|c|c|}
\hline & \multirow{2}{*}{$\begin{array}{l}\text { All } \\
\text { Countries }\end{array}$} & \multicolumn{2}{|c|}{ Central Africa } & \multicolumn{2}{|c|}{ Eastern Africa } & \multicolumn{2}{|c|}{ Northern Africa } & \multicolumn{2}{|c|}{ Northern Africa } & \multicolumn{2}{|c|}{ West Africa } \\
\hline & $\ln G D P$ & & $\ln G D P$ & $\ln T R M$ & $\ln G D P$ & $\ln T R M$ & $\ln G D P$ & $\ln T R M$ & $\ln G D P$ & $\ln T R M$ & $\ln G D P$ & $\ln T R M$ \\
\hline $\begin{array}{l}\text { W- } \\
\text { bar }\end{array}$ & 5.3214 & 3.2649 & 4.1815 & 2.9509 & 5.7525 & 4.2958 & 2.0685 & 4.2959 & 7.1292 & 4.1324 & 4.5187 & 2.2144 \\
\hline $\begin{array}{l}\text { z- } \\
\text { bar }\end{array}$ & $\begin{array}{l}21.1707 * * * \\
(0.0000)\end{array}$ & $\begin{array}{l}11.0958 * * \\
(0.0230)\end{array}$ & $\begin{array}{l}5.5106^{*} \\
(0.0589)\end{array}$ & $\begin{array}{l}3.3791 * * \\
(0.0450)\end{array}$ & $\begin{array}{l}12.1156^{* * *} \\
(0.0040)\end{array}$ & $\begin{array}{l}8.4026^{* *} \\
(0.0139)\end{array}$ & $\begin{array}{l}1.6894 \\
(0.4590)\end{array}$ & $\begin{array}{l}5.2113^{*} \\
(0.0790)\end{array}$ & $\begin{array}{l}13.7052 * * * \\
(0.0050)\end{array}$ & $\begin{array}{l}7.0042 * * \\
(0.0200)\end{array}$ & $\begin{array}{l}9.3095^{* *} \\
(0.0430)\end{array}$ & $\begin{array}{l}3.2129 \\
(0.2510)\end{array}$ \\
\hline $\begin{array}{l}\text { Z- } \\
\text { bar } \\
\text { til. }\end{array}$ & $\begin{array}{l}16.5834 * * * \\
(0.0000)\end{array}$ & $\begin{array}{l}8.4565^{* *} \\
(0.0230\end{array}$ & $\begin{array}{l}4.2705^{*} \\
(0.0580)\end{array}$ & $\begin{array}{l}2.5511^{* *} \\
(0.0450)\end{array}$ & $\begin{array}{l}9.5167 * * * \\
(0.0040)\end{array}$ & $\begin{array}{l}6.5209 * * \\
(0.010)\end{array}$ & $\begin{array}{l}1.2033 \\
(0.4680)\end{array}$ & $\begin{array}{l}4.0443^{*} \\
(0.0790)\end{array}$ & $\begin{array}{l}10.8299 * * * \\
(0.0050)\end{array}$ & $\begin{array}{l}5.4245^{* *} \\
(0.0200)\end{array}$ & $\begin{array}{l}7.2427 * * \\
(0.0430)\end{array}$ & $\begin{array}{l}2.3249 \\
(0.2510)\end{array}$ \\
\hline
\end{tabular}

Note: $* * *$, and $* * *$ denote statistically significant at $10 \%, 5 \%$ and $1 \%$ significant levels respectively. The $\mathrm{H}_{0}: \operatorname{lnTRM}$ does not Granger-cause lnGDP and lnGDP does not granger-cause $\ln$ TRM for Equations 4 and 5 respectively. The $\mathrm{H}_{1}$ : $\ln$ TRM does granger-cause lnGDP and lnGDP does granger-cause lnTRM for Equations 4 and 5 respectively. 


\section{SUMMARY AND CONCLUSION}

The study which covers the period 1995-2016 aims at modelling tourism and economic growth nexus in Africa. We employ panel ARDL and Granger non-causality test. Findings of the study indicate that tourism is a requisite for economic growth in Africa and in Southern Africa in the long run, but slightly dampens growth in the short run. Similarly, in the long run, we find tourism to be indispensable for the growth of the economy of North Africa, Southern and Western Africa. However, the contribution of tourism to the growth of the economy of these regions in the short run is dispensable. In Central Africa, tourism is rather neutral in influencing economic growth - it has a mixture of insignificant negative short run and insignificant positive long run impact on growth. The causal relationship confirms a bidirectional relationship between tourism and economic growth in Africa. Similarly, we confirm a two-way causality between tourism and economic growth in Central, Eastern and Northern Africa. However, we establish a one-way causality between tourism and economic growth in Northern and Western Africa. In Northern Africa, we find causality from tourism to economic growth, i.e., we confirm TLEG hypothesis, while in Western Africa we confirm that economic growth granger causes tourism, i.e., EDTG hypothesis. 
[1] Antonakakis, N., Dragouni, M. \& Filis, G. (2015). How Strong is the Linkage between Tourism and Economic Growth in Europe? Economic Modelling 44, 142-155.

[2] Antonakakis, N., Dragouni, M., Eeckel, B. \& Filis, G. (2016). Tourism and Economic Growth: Does Democracy Matter? Annals of Tourism Research. http://dx.doi.org/10.1016/j.annals.2016.09.018.

[3] Arslanturk, Y., Balcilar, M. \& Ozdemir, Z.A. (2011). Time-Varying Linkages between Tourism Receipts and Economic Growth in a Small Open Economy. Economic Modelling 28, 664-671.

[4] Atan, S. \& Arslanturk, Y. (2012). Tourism and Economic Growth Nexus: An Input Output Analysis in Turkey. Social and Behavioural Sciences 62, 952-956.

[5] Blackburne, E. F. \& Frank, M. W. (2007). Estimation of Nonstationary Heterogeneous Panels. Stata Journal 2, $197-208$.

[6] Breitung, J. (2000). The Local Power of Some Unit Root Tests for Panel Data. Advances in Econometrics 15, $161-177$.

[7] Chou, M. C. (2013). Does Tourism Development Promote Economic Growth in Transition Countries? A Panel Data Analysis. Economic Modelling 33, 226-232.

[8] Chulaphan, W. \& Barahona, J. F. (2017). Contribution of Disaggregated Tourism on Thailand's Economic Growth. Kasetsart Journal of Social Sciences. http://dx.doi.org/10.1016/j.kjss.2017.07.012.

[9] Croes, R. R. (2006). A Paradigm Shift to a New Strategy for Small Island Economies: Embracing Demand Side Economics for Value Enhancement and Long-Term Economic Stability. Tourism Management 27(3), 453-465.

[10] Dogru, T. \& Bulut, U. (2017). Is Tourism an Engine for Economic Recovery? Theory and Empirical Evidence. Tourism Management. http://dx.doi.org/10.1016/j.tourman.2017.06.014.

[11] Dumitrescu E, L. \& Hurlin, C. (2012). Testing for Granger Non-Causality in Heterogeneous Panels. Economic Modelling 4, 1450-1460.

[12] Fahimi, A., Akadiri, S. S., Seraj, M. \& Akadiri, A. C. (2018). Testing the Role of Tourism and Human Capital Development in Economic Growth: A Panel Causality Study of Micro States. Tourism Management Perspectives 28, $62-70$.

[13] Habibi, F., Rahmati, M. \& Karimi, A. (2018). Contribution of Tourism to Economic Growth in Iran's Provinces: GDM Approach. Future Business Journal 4, 261-271.

[14] Hadri, K. (2000). Testing for Stationarity in Heterogeneous Panel Data. Economics 2, 148-161.

[15] Harris, R. D. \& Tzavalis, E. (1999). Inference for Unit Roots in Dynamic Panels Where the Time Dimension is Fixed. Journal of Econometrics 2, 201-226.

[16] Im, K. D, Pesaran, M. \& Shin, Y. (2003). Testing for Unit Roots in Heterogeneous Panels. Journal of Econometrics 1, $53-74$.

[17] Jalil, A., Mahmood, T. \& Idrees, M. (2013). Tourism-Growth Nexus in Pakistan: Evidence from ARDL Bounds Tests. Economic Modelling 35, 185-191.

[18] Koens, A., \& Wood, R. C. (2017). An Analysis of International Employment Levels in Hospitality Occupations Using Secondary Statistics. International Journal of Tourism Research 19(5), 496-504.

[19] Kumar, R. R. \& Stauvnermann, P. J. (2016). The Linear and Non-linear Relationship between Tourism Demand and Output per. Worker: A Study of Sri Lanka. Tourism Management Perspective 19, 109-120,

[20] Lee, C. \& Chang, C. (2008). Tourism Development and Economic Growth: A Closer Look at Panels. Tourism Management 29, 180-192.

[21] Levin, A. Lin, C. F. \& Chu, C. S, J. (2002). Unit Root Test in Panel Data: Asymptotic and Finite-Sample Properties. Journal of Econometrics 1, 1-24.

[22] Li, K. X., Jin, M. \& Shi, W. (2017). Tourism as an Important Impetus to Promoting Economic Growth: A Critical Review. Tourism Management Perspectives http://dx.doi.org/10.1016/j.tmp.2017.10.002. 
[23] Maddala, G. S. \& Wu, S. (1999). A Comparative Study of Unit Root Tests with Panel Data and a New Simple Test. Oxford Bulletin of Economics and Statistics 61, 631-652.

[24] Oh, C. (2005). The Contribution of Tourism Development to Economic Growth in the Korean economy. Tourism Management $26,39-44$.

[25] Ohlan, R. (2017). The Relationship between Tourism, Financial Development and Economic Growth in India. Future Business Journal 3, 9-22

[26] Papatheodorou, A. (1999). The Demand for International Tourism in the Mediterranean Region. Applied Economics 31(5), 619630.

[27] Pesaran, M. H. (2007). A Simple Panel Unit Root Test in the Presence of Cross-Sectional Dependence. Journal of Applied Economics 22, 265-267.

[28] Salisu, A. A. \& Isa, K. O. (2017). Revisiting the Oil Price and Stock Market Nexus: A Nonlinear ARDL Approach. Economic Modelling 66, 258-271.

[29] Schubert, F. S., Brida, J. G. \& Risso, W. A. (2010). The Impacts of International Tourism Demand on Economic Growth of Small Economies Dependent of Tourism. Tourism Management 32(2), 377-385.

[30] Shin, Y., Yu, B. \& Greenwood-Nimmo, M. (2014). Modelling Symmetric Cointegration and Dynamic Multipliers in an ARDL Framework. In: Horace, W. C.

[31] Tang, C. F. \& Tan, E. U. (2015). Does Tourism Effectively Stimulate Malaysia's Economic Growth? Tourism Management 46, 158-163.

[32] UNWTO (2017). Tourism Highlights 2017 Edition.

[33] World Tourism Organization (2014). UNWTO Tourism Highlights. Retrieved from http://mkt.unwto.org .on $20^{\text {th }}$ January 2019.

[34] World Travel and Tourism Council (2015). Travel and Tourism Economic Impact: European Union. London, UK: World Travel and Tourism Council.

[35] WTTC (2011). Annual Reports, Progress and Priorities 2011/11. The World Travel and Tourism Council.

[36] WTTC (2018). Travel and Tourism Economic Impact 2018 World. Retrieved from www.wttc.org on $24^{\text {th }}$ January 2019.

[37] Zhang, L. \& Gao, G. (2016). Exploring the Effects of International Tourism on China's Economic Growth, Energy Consumption and Environmental Pollution: Evidence from a Regional Panel Analysis. Renewable and Sustainable Energy Reviews 53, 225-234.

[38] Zumba, Y. I. \& Adeshola, F. G. (2018). Company Income Tax, Petroleum Profit Tax and Government Revenue in Nigeria: The Role of Exchange Rate and Inflation. Tax Academy Research Journal 2(2), 50-68. 